\title{
Russian Religious-Philosophical Renaissance as a Phenomenon of Spiritual Culture
}

\author{
Marina Cherkasova
}

\author{
Victoria Mashko
}

Irina Mordvinceva

Vladimir Khamov

Vadim Cherkasov

Branch of the Russian State Social University in Kamensk-Shakhtinsky

Email: kamensk@rgsu.net

\section{Doi:10.5901/mjss.2015.v6n3s4p103}

\section{Abstract}

The radical transformation of Russian culture in the perestroika and post-perestroika period, inevitably led to a fundamental rethinking of the attitude to religion. Transformation of assessing the significance of religion for Russian culture can be represented in the form of a pendulum, sharply swinging in the direction from the militant, uncompromising atheism, which had the status of official ideology in the USSR, to unconditionally positive assessment of Orthodoxy as a religion traditional for Russia. To the point was described the degree of radicalism of changing attitudes to religion in contemporary Russia academician L. N. Mitrokhin's speech at the III Congress of Philosophy. He noted that 15 years ago "official, escort godlessness was rejected" and "the era of religious euphoria, which were summed up in the belief that without religion (it was mostly about Orthodoxy) Russia has no future, was began". (Rationality and culture on the threshold of the III Millennium, 2003, p. 84) The new status of religiosity in contemporary Russia makes a very topical solution of a number of questions. It is necessary to understand: first, why does a movement from atheism to religion take place. Secondly, weather there is any reason to suppose that Orthodoxy will become the spiritual leader in modern Russia. And thirdly, are the modern Russians in need of religion, and in which namely. Informed decision of these questions is possible only at referring to the study of the history of religion in Russia of the Soviet period and makes necessary the depth analysis of religious processes in modern Russia.

Keywords: religious-philosophical Renaissance, spiritual culture, Orthodoxy, the evolution of religiosity.

\section{Introduction}

In the late 80's - early 90-ies of the past century for the Russian Orthodox Church ended the era of total persecution. For the Church opportunities not only of unimpeded withinchurch life, missionary work, but also active participation in solving social problems and cultural life of Russia are opened. Until all the activities of the Church was proceeding under hard ideological control, and was restricted by the temple protection. Any social activity was strictly forbidden in the Soviet Union by religious organizations. The exception applied only to activities in the international arena, since the Soviet state was considered by the Russian Orthodox Church as one of tools of its foreign policy influence. Abandoning the plans for the immediate physical destruction of the Church, the Soviet government adopted the policy of isolation of the Church within the country.

The Russian Church has entered the era of freedom, being in a very difficult position. Despite the fact that many people flocked to its gates, there was catastrophic lack of temples, priests, especially the educated, liturgical literature. During the long years of existence in the artificially created ghettos the skills of missionary and catechetical work were actually lost. Almost none of the priests had no skills to participate in the social work of the Church. From the side it might seem that even if within church life will enter in the near future to normal course, it will not be possible to speak about the active participation of the Church in social and cultural life of our country in the coming years. However, this has not happened. After a very short time, the Russian Orthodox Church began to play a prominent role in the life of the Russian society. And now it would be hard to find the public sphere, in which did not participate, along with other civil society actors, the Russian Orthodox Church. The Church seeks to play an active role in the life of our society, this is a natural 
phenomenon. The Russian Orthodox Church is a religious organization, with which the majority of people in modern Russia identify themselves, it reaches itself as an integral part of society and the keeper of the traditional values of Russian culture. Clerics always emphasize in their public statements that, under the Constitution, the Church is separated from the state, but it is not separated from society, and cannot stand aside from society's problems decisions.

\section{Literature Review}

Russia can not be understand by mind..." Could the poet know, that these words in the XXI century, his descendants will say it with irony, often angry? The most dangerous thing in the current state of Russian society - not the economic crisis, but the growing state of spiritual emptiness, which covers a huge layers of Russians, including youth and adolescents. With what will be filled this emptiness, what values will be strengthened in society - centeredness and individualism or ideas of goodness and justice - such will be our future.

However, there is a serious question - what is meant by spirituality? After all, an abstract concept can be filled with different contents. It is fitting to recall the thought $\mathrm{N}$. And. Berdyaev that spirituality is sometimes cruel, inhuman, when live people are sacrificed to the idea, and let the great. It is appropriate to recall the thought of N. A. Berdyaev that spirituality is sometimes cruel, inhuman, when concrete living peoples are sacrificed to the idea, though great. There are a lot of examples of such sophisticated spirituality in the history. It appears that for the concretization of the concept of "spirituality" one should refer to national traditions and values that have been evolved over the centuries. The development of man should be held in his native cultural environment, "raising and nurturing the personality" (P. A. Florensky), and not in the environment of so-called mass ersatz - culture. Therefore it is necessary to refer to our spiritual heritage, in particular to authentic Russian philosophical thought. The end of the XX century was marked by a growing interest not only in our country but also abroad. So, in March 1993, by the Transnational Institute (USA) V was organized the international conference on Russian philosophy. In May 1994 a conference entitled "Russian philosophy as a source of reevaluation of social values in modern Russia ", which was held in Italy. The interest in the XXI century was not lost. But, discussing the peculiarities, generic features of this phenomenon, philosophers, however, express doubt: is there an absolute unique and original Russian philosophy that distinguishes the Russian thinking from other philosophical traditions; is possible the division of philosophy on a national basis? It is impossible to agree that the answer to these questions is difficult. However, they should not create the impression, as it is sometimes, unfortunately, happens, as if we don't know what it is about. When we speak about Russian philosophy, we mean primarily the works of Russian thinkers, which cannot be viewed merely as applications or modifications that were created in the sphere of other people's thoughts, and original intellectual phenomenon. Such philosophy developed by N. A. Berdyev, S. N. Bulgakov, N. O, Lossky and other thinkers of the late XIX-early XX centuries, the time, which is usually called religious-philosophical Renaissance. Russian religious-philosophical Renaissance can be seen as the second, after the Slavophiles, wide religious attempt to overcome the social and cultural crisis that swept Russia. "Russian society by this time realized that rational pragmatism does not take root in the environment of the Russian people, has experienced a period of passion of German idealism of Kant, Fichte, Hegel and Schelling, and prepared the ground for the meeting, according to G. Florovsky, "the intelligence with the Church after the impetuous experience of nihilism, the denial and forgetting." (7, p. 53). The intellectual elite was rediscovering the world of Russian Holiness, ascetic monastic tradition, and was assessing the importance of the Orthodox asceticism for Russian culture. As a result, part of the Russian intelligence, according to S. Bulgakov, realized the futility of their exclusive concern to the " non-natural", began to think about "non-natural" values; appeared the mental movement, named "the new religious consciousness ".It actually was about a new religious consciousness, as this was not dogmatic, but creative twist to religion. Philosophers assumed that for the Orthodox Church time for renewal came. The Church in Russia, they believed, does not perform its most important task of beneficial effect on society, and it was time to make Christianity a powerful force, to make the transition from religious thought to the religious life. Turning to religion, the spiritual foundations of life was a kind of reaction to the expansion of materialism and positivism philosophy of atheism in the religious life, naturalism - in aesthetics, socio-civic pathos - in poetry.

Such view of religious-philosophical Renaissance is fair but not complete, as it expresses only the social aspect of the phenomenon. Religious-philosophical Renaissance cannot be considered as a separate, independent process. This is one of the stages of the process of the historical existence of Russian culture, the spiritual source of which is Orthodoxy throughout all of its sides: as a faith and as a Church, as a doctrine and as an institution, as a life and spiritual life. Thus, the semantic content of the philosophical process in Russia, including religious-philosophical Renaissance as one of its stages, includes the development, elaboration of Orthodoxy by means in the forms of philosophical reason. Authentic Russian philosophical tradition proceeds from an experienced soil of Orthodoxy, though, is not required to be 
exhausted. The worldview "diversity" of philosophical thought of the late XIX-early XX centuries confirms this. For example, F. Stepun, B. Yakovenko, G. Shpet, A. Vvedensky predominantly adhered "Western" orientation, believing that Russian philosophy must pass "creative skills" in the European school of thought, that will allow it to gain national and super national significance. In the Moscow psychological society, in contrast, by a focus on the development of own problems of Russian philosophy, mainly religious, was dominating. Russian liberal philosophers P. Novgorodtsev, B. Kistiakowsky and others focused attention on the justification of the development of civil society and legal state. In the center of the searches were supporters of the faith in Christian reconciliation, who were close to the ideas of Vladimir Solovyov and F. Dostoevsky on the virtues of the Russian soul and its world responsiveness. Despite such a mixture of sources of influence and traditions, each area was characterized by understanding of their roots and origins.

The article "The restoration of the relics" of P. Novgorodtsev ended with the conclusion: "Non political parties will save Russia, it will be raised by the light of eternal relics of national spirit".

In General, the definition of "religious-philosophical Renaissance" is rather arbitrary and reflects only a narrow sense of the spoken phenomena. The religious perspective is hardly dominant even for that part of philosophers, who are traditionally calling it religious. They were nominating ptoductive ideas on ontology, epistemology, ethics, aesthetics, philosophical anthropology, social philosophy. It is possible to say that Orthodoxy was taken by them as phenomenal ground for philosophizing. Christian doctrine was a mainstay in the attempt to resolve the problems, pulled out by the reality, was interpreted as a religion of social progress, community of salvation. The emphasis was on the initiative of man, led by the example of Jesus Christ. Part of the authors of the Renaissance (P.B. Struve \& S.L. Frank) fully recognized the reality of religious values, but by actively participating in the practice of political life, they preferred to see in religion a purely personal belief, considering that the positive effects of religion on society must be reflected in the General cultural and moral lifting each concrete person. Others (P.A. Florensky, S. Bulgakov) took a different position, considering historical functioning Church, with some modernization, a true institution of "reviving" of man and society. Finally, the third (D.S. Merezhkovsky \& N.A. Berdyaev) closely connected the absoluteness of God's will and human action, subjecting Christianity to the social and cultural interests. N. A. Berdyaev, as if giving an estimate of the situation "from the inside", wrote: "We had a cultural Renaissance, but it would be wrong to say that a religious Renaissance took place. For religious Renaissance lacked strong and focused will, there was just too great cultural sophistication, were elements of decadency in the attitudes of the cultural layer, and the upper cultural layer was too closed in itself". (Russia and Russian philosophical culture, 1990, p. 92).

\section{Methodology}

The methodological basis of the work was cultural, philosophical and historical concepts of Russian culture. In the basis for the lies the fundamental principles of knowledge and understanding of social phenomena: consistency, comprehensiveness, unity of historical and logical. In the work we used the comparative method and system analysis, methods of analogy, reconstructing the philosophical views of the thinkers on the basis of analysis of their texts. Interdisciplinary approach, focusing on the study of culture as a multidimensional phenomenon that allows fully and comprehensively to examine its phenomena, was implemented.

Methodological basis of research are the works of Russian philosophers N. A. Berdyaev, V. V. Zenkovsky y, L. P. Karsavin, N. O. Lossky, N. S. Trubetskoy, S. L. Frank, G. V. Florovsky, O. P. Florensky.

\section{Results}

All philosophical constructs are based on the religious content, but they do not coincide with the whole integrity of the Orthodox experience. What exactly the philosopher makes of it with his asset and what neglects, is decided subjectively, to the taste of the philosopher. One in religion is close to him, the other is alien, one inspires one another repels. Moreover, specific features of Orthodoxy - dogma, specific typological features - usually remain outside of philosophical interests. That is, the religious-philosophical Renaissance was mastering in the field of religious experience common horizons, and only in the later stages the relationship of philosophical thought with experienced religious foundation adopts more strict reflected nature - philosophy thinks about the whole phenomenon of Orthodoxy.

Analyzing the philosophical thought of the end of $\mathrm{X} 1 \mathrm{X}$-beginning of $\mathrm{XX}$ centuries, it is possible to identify some common features:

Panontologization. Philosophical thought of this phase is permeated by the desire for wholeness as the proper state of the world. Such aspirations are founded on the notion of the modern state of existence that is different from the empirical genesis, imperfect and flawed. Perfect genesis was once lost, disintegrated under the action of the elements of 
evil and sin. The purpose and meaning of human is to return this perfect being. In the question about the relationship of God and the world, of absolute and empirical being the philosophical idea came from the idea of the deep ties between the two horizons. This relationship is expressed in the "rooting" of the local existence in the Divine, the existence of "roots of creature in God". The meaning of being was understood as its internal relatedness with God, the ability and relevance of the created beings to imitate God was emphasized. Thus, in philosophical constructions occurs ontologization of many concepts, principles, and historically having ethical-deontological or epistemological status.

"We are philosophy". With panontologazation is connected the fact that S. Frank calls the "We-philosophy" of Russian philosophers - the conviction that the relationship of individuals between themselves is defined from above. It is explained and justified by religious certainty that all can be saved only together, and also by the subtle metaphysics of the person, an example of which is the interpretation of non - merging and the inseparability of the Trinity.

Anthropocentrism is dating back to the patristic idea of man "head of creature." It is assumed that the purpose of man is cosmic and theurgical mission, which is the work of "the gathering of creatures." The person must gather and transform the world into a living and harmonious whole, and not by the forcible restructuring, but the organic love and unity with all things in the world.

Panotizm. The panotizm of Russian thought is associated the anthropocentrism, confirming the view of man as the ultimate and perfect creation, the learning of which gives the key to other mysteries. The development of the doctrine of man was going through the solution of ethical problems. Philosophers have emphasized that only the human soul can reflect in its depth the harmony of the world, the Divine countenance.

Epistemological realism. A person, according to Russian philosophers, is connected with the world by thousands of threads, sees the world in penetrating in oneself and walking into the world. The person, who is not opposed to the world, but belongs to him, there is no reason to doubt the fundamental cognoscibility of the world. Moreover, doubtful is the suggestion that the person who is called upon to save the world, to unite it, is not endowed with the capacity to learn the truth of this world. Cognitive activity can occur in different forms and cannot be reduced only to the intellectual, rational species. Russian philosophers, comprehending selfless experiences of the Holy fathers, came to the conclusion that the claims of the logical mind on the self, not dependent on other cognitive powers of expression of truth give rise to contradictions and confusion. S. Bulgakov, exploring the nature of thinking, talks about "religious-intuitive foundations of all philosophizing". Rejecting these fundamentals, philosophy appears as a "religious herecyology... as the tragedy of thoughts that find no result" (Bulgakov, 1993, p. 43-44).

One cannot help but notice that in the West a similar thought flow was observed in the middle of the century. Therefore, quite common is the perspective on the religious-philosophical Renaissance as archaic, flawed philosophy, situated within the medieval tradition, in general, even only an imitation of philosophy. N. Lassic has warned from this view: "Russian religious philosophy is not a repetition of scholasticism, because it uses all the achievements of science and modern philosophy, especially modern highly advanced epistemology. Therefore, it should be said that Russian religious philosophy is a progressive achievement and is able to give new impetus to the development of Western thought" (Dostoyevsky, 1990, p. 174). Russian religious-philosophical Renaissance was the recognition of the crisis of the secular modern European culture and the search for the philosophical foundations of the future of mankind. The new world was seen by Russian philosophers of the Renaissance as the "new middle ages" with a different type of global community. The path to it, according to N. A. Berdyaev, was to take the whole XX century.

These features of mentioned philosophical thoughts of barrier era left its imprint on its appearance. Russian thinkers felt cramped in the academic framework of Western philosophy. They did not seek to create closed philosophical systems. Therefore, it is not surprising that Western researchers, accustomed to strict systematic philosophy, estimated Russian philosophy as a "vague idea of prophetist character, trying to open and offer to the society a recipe for righteous living" (About the perception of missed, 1995, pages 241-242). A. S. Losev rightly saw the reason for such "an acute shortage of philosophical systems" "not only in the external environment, but rather, and above all, in the internal structure of the Russian philosophical thinking" (Essays on the history of Russian philosophy, 1991, p. 28). The researcher, guided by intuition, does not consider rationalistic constructions so important to spend a lot of effort on their improvement. Sometimes he expressly declares the refusal build system, as did N. A. Berdyaev, accusing Kant in "building of a spiritual barracks". Describing the Russian philosophical thinking, N. A. Berdyaev wrote: "the founders of Slavophilism had not left big philosophical tracts, has not established a system, maybe such a philosophy and should not be a system... They overcame German idealism and Western abstract philosophy with the belief that the spiritual life of Russia gives birth of the highest realization of everything, the highest organic form of philosophy" (Berdyaev, N. \& Khomyakov A.S., 1912, p. 69). These words realistically can be attributed to the thinkers of the religious-philosophical Renaissance. Refusing, sometimes deliberately, from building of systems, Russian philosophy tended to overcome the disunity of the individual philosophical areas and approaches. Perhaps the first such example was the Positive theory of 
the early Universe by V. Solovyov.

Speaking of Russian religious-philosophical Renaissance, in our view, it is possible to highlight another significant feature of philosophical thought of this era - the eschatologism. This trait is due to both by external and internal reasons. A feeling of impending tragedy, of an end was soaked in the atmosphere of barrier era. According to Berdyaev, all "felt that Russia was falling into an abyss, that old Russia is ending and there must be a new Russia, still unknown" (Berdyaev, 1905, p. 123).

Religious-mystical moods were clearly marked, above all, in the intelligence, which is understandable. The Russian intelligence is one of a kind. It cannot be called a class because it did not have a single economic base. Even less it was a political party in the conventional sense of the word. N. A. Berdyaev and others compared it to the order. Such a definition, perhaps, helps to better understand the special role of intellectuals in the life of the Russian people. The order was defined as a community of people who have subjected themselves to a certain lifestyle based on a particular worldview. Intelligence, one might say, was the "nerve" of society, than, in general, explains the increased interest of Russian philosophers to the problems of the soul, the inner struggle. A. F. Losev rightly pointed out: "Russian philosophy never dealt with something besides the soul, personality and inner "feat". And this soul, this personality and that inner act now have shuddered in a mystical horror, in terrible waiting of the end. Dostoyevsky undoubtedly was brilliant central figure of this new attitude "(Essays on the history of Russian philosophy, 1991).

This type of philosophy can be called existential. Chronologically, this type of philosophy explicated earlier, than it happened in Russia, and is usually associated with the name of S. Kiergaard. However in Russia, in the Russian environment it is unfolded in its entirety. According to V. Barrett, the author of "Irrational man" and "What is existentialism", remaining in these days significant research on the philosophy of existentialism, Russian philosophers brought in a kind of existential philosophy, the Russian vision of the world - "total aspiring to last, apocalyptic", and their work, "can show us the depth of philosophical thought in Eastern Europe».

\section{Deductions}

Taking advantages of the Russian religious-philosophical Renaissance, however, it is not possible not to see it's some drawbacks. "That what flourished on the pages of magazines and almanacs, about what hotly are de debating in the salons of Merezhkovsky and Morozova, in "the tower" of Ivanov, in edition of "Put" and "Musagete", was and still is a hothouse of culture. The Renaissance of Russian life did not take place". With this statement of A. Ermicheva is hard to disagree. First, this living movement was catastrrophic ragged at the stage of formation, unable to overcome many of the initial imperfections and barriers. There is a perception that 1922 was the year of death, the end of Russian philosophy. Of course, despite the forced emigration of the majority of thinkers of the religious-philosophical Renaissance, the development of the tradition was continued, but still, it was a different time and a different thinking. Secondly, the weakness of the Russian spiritual Renaissance was noted by philosophers. The reasons of it were different: the lack of a broad social base, the gap of the intelligence and the people, always accompanying the Russian history. It cannot be taken into account the striking solitude of representatives of the Renaissance. Calling for mutual agreement, togetherness, unity, they, nevertheless, were covered by inter-struggle. As in the ballad of A. K. Tolstoy: brothers saw the truth, but from different sides, because "everyone was telling the truth in his own way", refusing the others.

The question naturally arises - if is religious-social synthesis possible at all, or is it utopia? It is hardly possible to unambiguously answer it. But, one should think, it is not accidentally that Moscow University intellectuals in our days arises the idea of creating a movement of non-violence under the motto "unity", which theory was developed by V. Solovyov and F. M. Dostoevsky, and after them - N. A. Berdyaev, N. O. Lossky, S. Bulgakov and other representatives of Russian religious-philosophical Renaissance. Therefore we may hope that the philosophical thought of the turn of the century will get its real revival, and not as a fashion trend, but as consciously sought intellectual and spiritual value.

\section{Conclusion}

In the Russian spiritual tradition "religious-philosophical Renaissance" carries a deeper sense and has many meanings. Unambiguous definition of the phenomenon does not exist yet. It has a pronounced personal principle, is largely determined by the beliefs about the fundamental philosophical problems and expresses own spiritual experiences conceptions of individual and national life, of the soul and mentality, religion and culture. "Assessing the role of spiritual forces in the development of Russian society, P. K. Kurochkin says: "Turn to the issue of human, in particular to its social activity, is the most important aspect of modernization of modern religion". 


\section{References}

Berdyaev, N. \& Khomyakov A.S. (1912). Moscow in 1912.

Berdyaev, N. (1905) About the new religious consciousness // the Questions of life. book.9.

Bulgakov, S (1993). Essays in 2 volumes. M.

Dostoyevsky, O. (1990). Creative work of Dostoevsky in Russian thought, 1881-1931 Collection of articles.

Russia and Russian philosophical culture (1990). The philosophers of the Russian post-revolutionary countries. A collection of articles. Moscow.

Essays on the history of Russian philosophy (1991). Losev. Radloff. Shpet, Sverdlovsk.

Florovsky, G. (1991). Ways of Russian theology. Vilnius.

Hagemeister. About the perception of missed (1995). Russian thought in the European context // Questions of philosophy. №11.

Pro et contra (1994). A collection of articles. SPb.

III Russian Philosophical Congress (2003). "Rationality and culture on the threshold of the III Millennium." Welcomes and plenary lectures of the Third Russian Congress of Philosophy. Rostov-on-Don. 